\title{
AMS RADIOCARBON DATING OF A SHELL FISHHOOK FROM SANTA ROSA ISLAND, CALIFORNIA
}

\author{
Torben C Rick
}

Department of Anthropology, University of Oregon, Eugene, Oregon 97403-1218 USA. Email: torrey@ oregon.uoregon.edu.

\begin{abstract}
Several single-piece shell fishhooks from CA-SRI-43 on Santa Rosa Island were dated by association to roughly $5500 \mathrm{cal}$ BP and were argued to be among the oldest specimens in the region. Direct accelerator mass spectrometry (AMS) radiocarbon dating of one of these hooks provided a date of $560 \mathrm{cal} \mathrm{BP}$, however, making it about 5000 yr younger than originally presumed. This younger date is more consistent with the regional shell fishhook chronology and demonstrates the importance of obtaining direct AMS ${ }^{14} \mathrm{C}$ dates to refine artifact and site chronologies.
\end{abstract}

\section{INTRODUCTION}

Single-piece fishhooks, usually made from abalone, mussel, or Norris top shells, were among the most important subsistence technologies for Native peoples of the central and southern California coast (Strudwick 1985, 1986). These artifacts appear to correlate with significant increases in the amount and types of fish captured, and had important impacts on human subsistence strategies, population growth, and sociopolitical developments (Glassow 1996; King 1990; Raab et al. 1995; Salls 1988; Strudwick 1985, 1986). To define the chronology of these important artifacts, most researchers have relied on associated ${ }^{14} \mathrm{C}$ dates (Glassow 1996:134; King 1990:83; Raab et al. 1995; Strudwick 1985, 1986; and others), with comparatively few studies focused on direct accelerator mass spectrometry (AMS) dating of the actual specimens (but see Koerper et al. 1988, 1995).

In this paper, I present an AMS date obtained from a single-piece shell fishhook from the Fox Site (CA-SRI-43) on Santa Rosa Island (Figure 1, Table 1). This and several other hooks were dated by association to $4790 \pm 90$ and $5370 \pm 150$ BP (Orr 1968:100, 184-7), making their chronological placement anomalous with the notion that most fishhooks are generally younger than about 2500 years old (Glassow 1996:134, 1997:153; King 1990:231; Strudwick 1985). I present contextual information for the CA-SRI-43 deposits, supply a brief perspective on the origins and significance of the single-piece shell fishhook, and offer new insights on the chronology of this important artifact type.

\section{SITE BACKGROUND AND CONTEXT}

CA-SRI-43 is located on a relatively broad, flat ridge between Tecolote and Arlington canyons on northwestern Santa Rosa Island. The site covers an area roughly $30 \times 50 \mathrm{~m}$ wide and is situated about $0.75 \mathrm{~km}$ from the coast at an elevation of approximately $100 \mathrm{~m}$. During the 1950s, Orr (1968: 182) excavated three $5 \times 5 \mathrm{ft}$ (roughly $1.5 \times 1.5 \mathrm{~m}$ ) units at the site, including eight human burials and the remains of four small fire pits. He also dug an $8 \times 100 \mathrm{ft}(2.4 \times 30.5 \mathrm{~m})$ trench at roughly 1 inch $(2.5 \mathrm{~cm})$ intervals using a jeep with a blade attachment to form a crude dozer (Orr 1958:2, 1968). ${ }^{1}$ The CA-SRI-43 deposits consist of a relatively fine, compact soil, terminating at a depth of roughly 26 inches (66 cm; Orr 1968). Most of the sediments from the units were screened over 1/8inch mesh, but no screens were used on the trench materials.

Roughly 164 artifacts from CA-SRI-43, including six abalone and mussel shell fishhooks, triangular microdrills, Olivella lipped, wall, and callus beads, a modified swordfish bill, and mortars and pestles were recovered during the extensive excavations (Orr 1968:186). Precise provenience for the

${ }^{1}$ A review of Orr's catalog and site map at the SBMNH indicates that he may have excavated five units at the site rather than three as indicated in Prehistory of Santa Rosa Island. Size estimates for his trench also vary between $8 \times 100 \mathrm{ft}$ and $8 \times 40 \mathrm{ft}$. Review of the site map suggests the trench was $8 \times 100 \mathrm{ft}$ in area. 
shell fishhooks is not currently available, but a catalog of Orr's collections for CA-SRI-43 at the Santa Barbara Museum of Natural History (SBMNH) lists the provenience for the dated fishhook (Cat. \# 4376) and an abalone shell fishhook as Sq. 16M, L. 5. This appears to refer to Unit 15M and possibly to level 5 .

Two uncorrected ${ }^{14} \mathrm{C}$ dates of $4790 \pm 90$ and $5370 \pm 150 \mathrm{BP}$ on marine shells excavated from the CASRI-43 deposits led Orr (1968:187; see also Fergusson and Libby 1962:110; Olson and Broecker 1961:170) to conclude that the site and shell fishhooks dated to the Middle Holocene, making them the oldest fishhooks in the region. It should be noted, however, that the microblades and most of the Olivella bead types recovered from the site generally date to after about 1,000 years ago, suggesting the site also had Late Holocene occupations (Glassow 1997:153). To determine the age of one of the CA-SRI-43 shell fishhooks, I obtained a specimen from the SBMNH for AMS ${ }^{14} \mathrm{C}$ analysis.

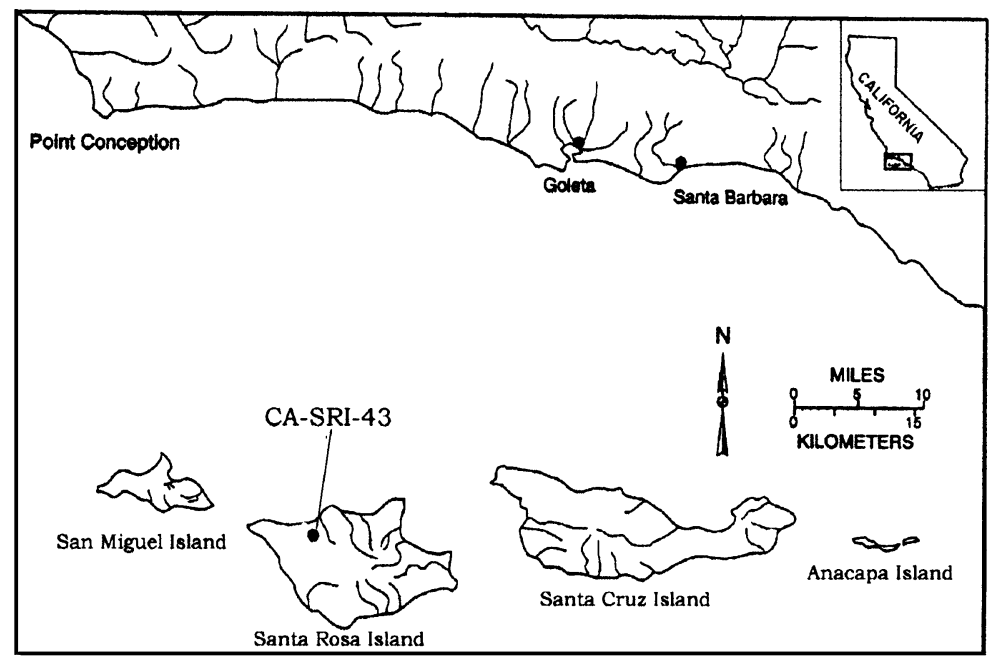

Figure 1 Location of CA-SRI-43 and Santa Rosa Island

Table 1 Radiocarbon dates for CA-SRI-43 ${ }^{\text {a }}$

\begin{tabular}{lllcccc}
\hline Material & Lab nr & Provenience & $\begin{array}{c}{ }^{13} \mathrm{C} / 12 \mathrm{C} \\
\text { meas. }\end{array}$ & $\begin{array}{c}\text { Uncor- } \\
\text { rected } \\
{ }^{14} \mathrm{C} \text { age }\end{array}$ & $\begin{array}{c}{ }^{13} \mathrm{C} / 12 \mathrm{C} \\
\text { adjusted }\end{array}$ & $\begin{array}{c}\text { Age range } \\
\text { (cal BP, 1 } \sigma \text { ) }\end{array}$ \\
\hline Shell Fishhook & OS-26072 & Sq. 16M, L. 5 & +0.59 & - & $1220 \pm 35$ & $630(560) 530$ \\
Mixed shell & UCLA-105 & Cemetery A: 9-12 in $(23-31 \mathrm{~cm})$ & N/A & $4790 \pm 90^{\mathrm{b}}$ & $5220 \pm 90$ & $5460(5310) 5260$ \\
Red abalone & L-446B & 14 M: 18-24 in $(46-61 \mathrm{~cm})$ & N/A & $5370 \pm 150$ & $5800 \pm 150$ & $6160(5930) 5770$ \\
\hline
\end{tabular}

aAll dates were calibrated using Calib 4.3 (Stuiver and Reimer 1993, 2000). A $\Delta \mathrm{R}$ of $225 \pm 35 \mathrm{yr}$ was used for all shell samples, and ${ }^{13} \mathrm{C} /{ }^{12} \mathrm{C}$ ratios were either determined by the ${ }^{14} \mathrm{C}$ labs, or an average of +430 yr was applied (Erlandson 1988).

${ }^{\mathrm{b}}$ This date was reported as $4800 \pm 100 \mathrm{BP}$ by Orr (1968:187), but review of the laboratory records indicate that it actually dates to $4790 \pm 90 \mathrm{BP}$ (Fergusson and Libby 1962:110). Records at the SBMNH also list L-446a as the laboratory number.

\section{METHODS}

The broken tip of a $1.2 \mathrm{~cm}$ long, burned mussel shell hook was selected for dating (Figure 2). A 50 $\mathrm{mg}$ fragment of the fishhook was removed from the larger specimen and sent to the National Oceanic Sciences AMS (NOSAMS) facility at Woods Hole Oceanographic Institute (WHOI) for analysis. The specimen was etched in dilute hydrochloric acid and rinsed in distilled water to remove any 
contaminants. It was then dried and converted to $\mathrm{CO}_{2}$ by reaction with $85 \%$ phosphoric acid under vacuum. Some of the specimen was then used to measure the ${ }^{13} \mathrm{C} /{ }^{12} \mathrm{C}$ stable isotope ratio while the rest was converted to graphite before being sent to the Center for Accelerator Mass Spectrometry (CAMS) at the Lawrence Livermore National Laboratory.

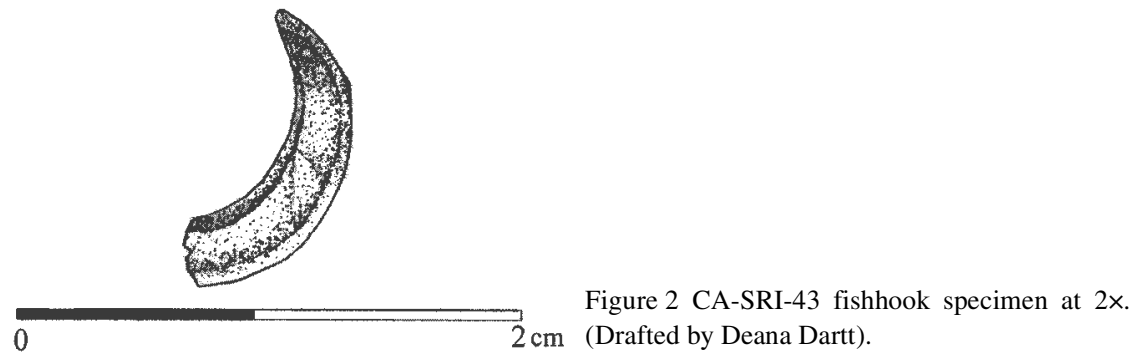

\section{RESULTS AND DISCUSSION}

The AMS analysis of the shell fishhook produced a ${ }^{13} \mathrm{C} /{ }^{12} \mathrm{C}$ corrected age of $1220 \pm 35 \mathrm{BP}$ (OS26072). Calibration of this date using CALIB 4.3 (Stuiver and Reimer 1993, 2000) and a $\Delta \mathrm{R}$ of 225 \pm 35 , yielded an intercept of $560 \mathrm{cal} \mathrm{BP}$ (AD 1390) and a range of 630 to $530 \mathrm{cal}$ BP (AD 1320-1420) at one standard deviation. This date corresponds with King's (1990:28) Late Period (AD 11501804), rather than the Middle Holocene age asserted by Orr. It also demonstrates that CA-SRI-43 contains at least two occupations, one at about $5500 \mathrm{cal}$ BP and another at roughly $560 \mathrm{cal}$ BP.

These findings support earlier claims made by Glassow (1997:153) that CA-SRI-43 contained both Late and Middle Holocene cultural deposits, with many of the artifacts (i.e., fishhooks, microblades, etc.) probably associated with the later occupation. Interestingly, both of Orr's dates were obtained from the lower half of the site deposits, leaving the upper $23 \mathrm{~cm}$ undated. It is likely that the shell fishhooks, microblades, and many of the beads come from the undated upper portions of the site, or from an intrusive burial or other feature not noted during excavation. Unfortunately, due to the limited provenience and field notes for the CA-SRI-43 assemblage further excavation is necessary to test these assertions.

Strudwick (1985:60-1, 1986:271-2, 279) argued that the single-piece fishhook may have first appeared in southern California roughly $5000 \mathrm{yr}$ ago or earlier, an estimate based partly on the specimens from CA-SRI-43. The revised age of the CA-SRI-43 fishhook, however, follows the general chronological trend for these artifacts noted by Glassow (1996:134), King (1990:83), Strudwick (1985:58-9) and others, which suggests most hooks date after about 2500 years ago. Recent dates directly on shell fishhooks (Koerper et al. 1988, 1995; Salls 1988), and fishhook age estimates based on associated ${ }^{14} \mathrm{C}$ dates (Raab et al. 1995:14; Vellanoweth and Erlandson 1999:268), suggest that the earliest shell fishhooks may have first appeared in the region at roughly 3000-3500 cal BP. This is about 2000 years later than Orr (1968), Strudwick (1985:60-1, 1986:272, 279), and others have suggested. The research presented here provides an important cautionary tale, demonstrating that more shell fishhooks and other artifacts need to be directly AMS dated to securely identify their chronology and document potential site disturbances. Following the work of Koerper et al. (1995), Vellanoweth (2001), and others, I argue that systematic AMS ${ }^{14} \mathrm{C}$ dating of individual artifacts should be used as a strategy to refine artifact, site, and regional chronologies. 


\section{ACKNOWLEDGMENTS}

Financial support for this project was supplied by the James A Bennyhoff Memorial Award given by the Society for California Archaeology. Jon Erlandson, René Vellanoweth, John Johnson, Mike Glassow, Doug Kennett, Kelsey Gerhard, and Peter Paige provided a variety of insightful comments on this and other related topics. J Johnson, Linda Agren, Fred Schaeffer, and Jan Timbrook graciously helped reconstruct Orr's research at CA-SRI-43 and provided access to the specimen and unpublished notes, maps, and reports at the SBMNH. Financial support for ${ }^{14} \mathrm{C}$ dating was also supplied by NSF Cooperative Agreement OCE-9807266 awarded to NOSAMS. This project was carried out in collaboration with Channel Islands National Park, and I thank Ann Huston and Don Morris for their support. Finally, I thank A J T Jull, Kim Elliott, an anonymous reviewer, and the editorial staff of Radiocarbon for assistance in the revision and production of this manuscript.

\section{REFERENCES}

Erlandson, JM. 1988. Cultural evolution and paleogeography on the Santa Barbara coast: a 9600 -year ${ }^{14} \mathrm{C}$ record from southern California. Radiocarbon 30(1): 25-39.

Fergusson GJ, Libby WF. 1962. UCLA radiocarbon dates I. Radiocarbon 4:109-14.

Glassow MA. 1996. Purismeño Chumash prehistory: maritime adaptations along the southern California coast. Fort Worth: Harcourt Brace College Publishers.

Glassow MA. 1997. Research issues of importance to coastal California archaeology of the middle Holocene. In: Erlandson JM, Glassow MA, editors. Archaeology of the California coast during the middle Holocene. Los Angeles: University of California, Institute of Archaeology. Perspectives in California Archaeology 4:151-62.

King CD. 1990. Evolution of Chumash society: a comparative study of artifacts used for social system maintenance in the Santa Barbara Channel region before $A D$ 1804. New York: Garland Publishing.

Koerper HC, Jull A, Linick T, Toolin L. 1988. A Tandem Accelerator Mass Spectrometer (TAMS) C-14 date for a Haliotis fishhook. Pacific Coast Archaeological Society Quarterly 24(4):49-53.

Koerper HC, Prior C, Taylor RE, Gibson RO. 1995. Additional accelerator mass spectrometry (AMS) radiocarbon assays on Haliotis fishhooks from CA-ORA378. Journal of California and Great Basin Anthropology 17(2):273-9.

Olson EA, Broecker WS. 1961. Lamont natural radiocarbon measurements VII. Radiocarbon 3:141-75.

Orr PC. 1958. Report on the 11th Santa Rosa Island expedition of the Santa Barbara Museum of Natural His- tory, 1957. Manuscript on file Santa Barbara Museum of Natural History.

Orr PC. 1968. Prehistory of Santa Rosa Island. Santa Barbara Museum of Natural History.

Raab LM, Porcasi J, Bradford K, Yatsko A. 1995. Debating cultural evolution: regional implications of fishing intensification at Eel Point, San Clemente Island. $P a$ cific Coast Archaeological Society Quarterly 31(3):327.

Salls RA. 1988. Prehistoric fisheries of the California Bight. Ph.D. dissertation. University of California, Los Angeles.

Stuiver M, Reimer PJ. 1993. Extended ${ }^{14} \mathrm{C}$ data base and revised Calib $3.0^{14} \mathrm{C}$ age calibration program. Radiocarbon 35(1):215-30.

Stuiver M, Reimer PJ. 2000. Calib 4.3 Radiocarbon Calibration Program 2000. Quaternary Isotope Lab, University of Washington.

Strudwick IH. 1985. The single-piece circular fishhook: classification and chronology. Pacific Coast Archaeological Society Quarterly 21(2):32-69.

Strudwick IH. 1986. Temporal and areal considerations regarding the prehistoric circular fishhook of coastal California. M.A. thesis. California State University, Long Beach.

Vellanoweth RL. 2001. AMS radiocarbon dating and shell bead chronologies: middle Holocene trade and interaction in western North America. Journal of Archaeological Science. In press.

Vellanoweth RL, Erlandson JM. 1999. Middle Holocene fishing and maritime adaptations at CA-SNI-161, San Nicolas Island, California. Journal of California and Great Basin Anthropology 21(2):257-74. 